\title{
The correct name for Castanha de cutia (Couepia edulis (Prance) Prance - Chrysobalanaceae)
}

Ghillean T. Prance $\left({ }^{*}\right)$

\begin{abstract}
In 1972 the author described the new species Acioa edulis (Chrysobalanaceae) to name the Cas. tania de cutia, a plant which is economically important because of its edible fruit. The original description was based on fruiting material only. Recently collected flowering material has shown that the original generic assignment was incorrect, and so it is now transferred to Couepia the correct genus, and the flowers are described for the first time.
\end{abstract}

\section{INTRODUCTION}

In Prance (1972b) I described the new species Acioa edulis to accomodate the plant known locally as Castanha de cutia. This plant is of considerable local economic importance for its edible cotyledons, and for its use for cooking oil and oil for soap-making. Although first collected in 1933, this species was only known in fruit until we made a special field trip in 1975 to collect the flowers. The flowering material has shown that my original generic assignment was incorrect, and that in fact it is a species of Couepia. The leaves and fruit resemble Acioa, but the flowers are clearly those of Couepia. Accordingly the species is transferred here to the correct genus, and the flowers are described for the first time.

\section{NOMENCLATURE}

Couepia edulis (Prance) Prance, comb. nov. Acioa edulis Prance, Acta Amaz. 2(1): 12-16. 1972.

Type. Prance, Maas, Atchley et al 14015. Brażil, Amazonas, rio Ituxi, Boca do Curuquetê (holotype NY; isotypes, FHO, INPA, MG, US).

\section{DESCRIPTION OF FLOWERS}

Inflorescence a much branched, $5-10 \mathrm{~cm}$ long, slightly corymbose panicle; the rachis and branches glabrous. Receptacle conical and slightly curved near base, 6-7mm long, glabrous on exterior, the interior lined by an extremely thick disc with only a small hollow, the interior with pilose hairs below insertion of style, glabrous on other side. Sepals 5 . rounded, unequal, $3-5 \mathrm{~mm}$ long, glabrous on exterior, the margins ciliate, appressed puberulous on interior. Petals 5, white, caducous, glabrous, the margins ciliate. Stamens 17-20, inserted in 2 rows around half of the thick staminal ring, the other half of the ring without staminodes, with a circle of deflexed hairs inserted on interior at base of staminal ring, the filaments glabrous, the anthers dorsifixed. Ovary inserted at mouth of receptacle on the same side as stamens; glabrous on exterior, glabrous within, unilocular; ovules 2. Style inserted at base of ovary towards interior, the swollen base pilose, the filamentous portion glabrous, equalling stamens in length.

\section{FLOWERING MATERIAL STUDIED}

J. F. Ramos P 23251, Brazil, Amazonas, Coari, $\mathrm{km} \mathrm{6,} \mathrm{road} \mathrm{to} \mathrm{airport,} \mathrm{flowering} \mathrm{February} \mathrm{10,} 1975$ (INPA, MG, NY).

\section{Discussion}

The genus Couepia contains species groups of closely related species and taxonomically isolated species, see Prance (1972a). The taxonomically isolated species are quite distinct from one another and are hard to relate to each other. Couepia edulis belongs to this type of species as it is quite

(*) - Instituto Nacional de Pesquisas da Amazônia e B. A. Krukoff, Curator of Amazonian Botany, The New Yơk Botanical Garden. 


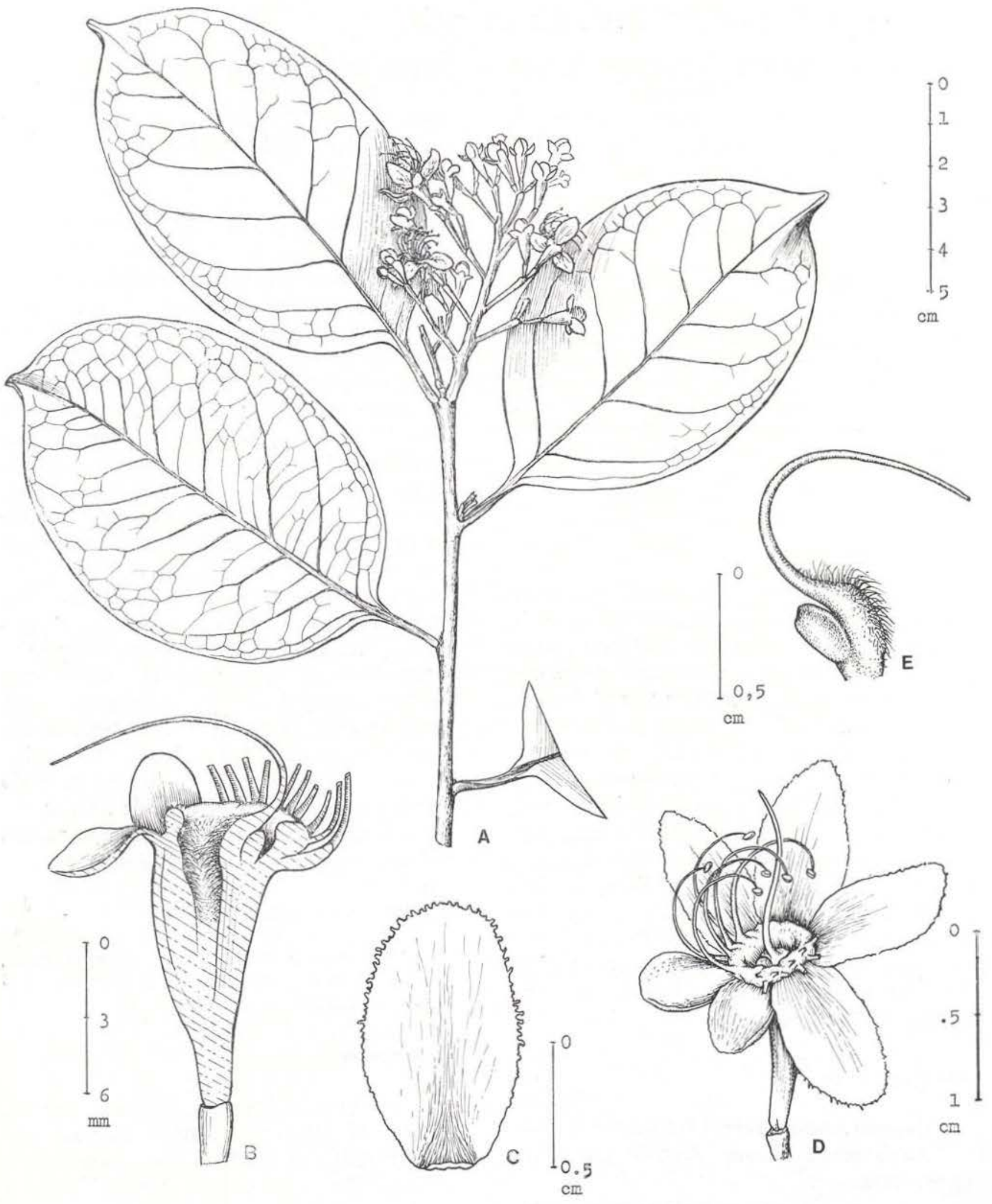

Fig. 1. Couepia edulis (Prance) Prance. A, habit; B, diagram of half flower; C, petal (caducous in open flower); D, flower with most of the stamens removed; E, ovary and style. (Des. by J. Dellome). 
distinct from any other species in the genus. The flowers with separate stamens, not fused into a strap, make this species a Couepia rather than Acioa.

The most interesting feature of $C$. edulis is that while it clearly belongs to Couepia, it is also close to the predominantly African Maranthes. Perhaps $C$. edulis forms a connecting link between the two genera. $C$. edulis belongs to Couepia rather than Maranthes because it has a unilocular ovary. However, at the base of the ovary there is often a slight trace of the vestiges of the spurious dissepiment which makes the ovary of Maranthes bilocular. C. edulis differs from other species of Couepia in the thickness of the disc tissue which is almost solid but has a small central cavity. In Maranthes the interior of the receptacle is completely solid. The entirely glabrous shining leaves of $C$. edulis look much more similiar to Acioa and Maranthes than to the majority of species of Couepia. While Maranthes is predominantly an African genus it was recently discovered in the Neotropics in Panama (see Prance 1968), and has one widely distributed species in Asia. The number of stamens and the large fruit with a thick hard endocarp separate $C$. edulis from the genus Hirtella, another genus close to Couepia.

The phenology of $C$. edulis appears to be quite constant since our efforts to collect flowers at other times of the year always failed, and the local people in Coari and Tefé observed that it flowers each year in February and March.

\section{ACKNOWLEDGMENTS}

I am most grateful to José $F$. Ramos who made the field trip to Coari to collect $C$. edulis. The field trip was financed by National Science Foundation grant GB -32575 . I am grateful to $\mathrm{Dr}$. Julio Dellome for preparing the figure, and to David G. Campbell who visited Coari and Tefé in 1974 to gather information on flowering time.

\section{RESUMO}

Em 1972 o autor descreveu a espécie nova, Acioa edulis (Chrysobalanaceae) para Castanha de cutia, uma planta de grande importancia por seus frutos comestíveis e oleaginosos. A descrição original foi baseada em material frutifero e sem flores. O material coletado em 1975 com flores mos. trou que a planta não pertence ao gênero Acioa mas à Couepia. Então, Acioa edulis é transferida para Couepia edulis (Prance) Prance, comb. nov. e as flores são descritas pela primeira vez.

\section{LITERATURE CITED}

Prance, G. T,

1968 - Maranthes (Chrysobalanaceae), A new generic record for America. Britonia, 20: 203-204.

1972a - Chrysobalanaceae. Flora Neotropica, 9, $410 \mathrm{p}$.

$1972 \mathrm{~b}-$ New and interesting Chrysobalanaceae from Amazonia. Acta. Amazonica, 2 (1) : 7-16. 